\title{
Pengaruh penggunaan pupuk organik terhadap pertumbuhan rumput gajah mini di lahan kering pada tahun kedua setelah penanaman
}

\section{The effect of manure application on growth of dwarflate napier grass on marginal land at the second year after establishment}

\author{
Ahmad Wadi ${ }^{*}$, Darmawan $^{2}$, Harifuddin ${ }^{1}$, \\ Muh. Irwan ${ }^{3}$, Fitriana Akhsan ${ }^{1}$ \\ ${ }^{1}$ Program Studi Agribisnis Peternakan, Politeknik Pertanian Negeri Pangkajene Kepulauan \\ ${ }^{2}$ Jurusan BudidayaTanaman Perkebunan, Politeknik Pertanian Negeri Pangkajene Kepulauan \\ ${ }^{3}$ Program Studi Peternakan, Universitas Muhammadiyah Sidenreng Rappang \\ ${ }^{*}$ Corresponding author: awadi15@yahoo.co.id
}

Diterima tanggal 04 Agustus 2019, Disetujui tanggal 30 Oktober 2019

\begin{abstract}
Abstrak
Aplikasi pupuk organik bermanfaat untuk pertumbuhan tanaman pakan. Di Indonesia, penggunaan rumput gajah mini dapat menjadi strategi yang efektif untuk meningkatkan pemanfaatannya sebagai sumber pakan yang cocok untuk ternak ruminansia. Tujuan dari penelitian ini adalah untuk mengetahui pengaruh pupuk organik terhadap pertumbuhan rumput gajah mini di lahan marginal pada tahun kedua setelah penanaman. Penelitian ini dilakukan di Desa Galung, Kecamatan Barru, Kabupaten Barru dari Januari hingga Agustus 2019. Desain penelitian adalah Rancangan Acak Lengkap (RAL) dengan 4 perlakuan dan 3 ulangan berurutan yang terdiri dari kontrol : $0 \mathrm{~kg}$, rendah: $5000 \mathrm{~kg}$, sedang: $10000 \mathrm{~kg}$, dan tinggi: $15000 \mathrm{~kg}$ pupuk organic /ha/tahun. Variabel yang diamati meliputi tinggi tanaman, panjang tanaman, jumlah anakan, luas permukaan daun, berat daun, berat batang, berat kering dan berat keseluruhan tanaman. Pengumpulan data dilakukan pada setiap umur tanaman 2 bulan untuk pemotongan pertama, kedua, ketiga, dan keempat. Semua data dianalisis dengan analisa statistik menggunakan SPSS. Hasil analisis keragaman menunjukkan bahwa perlakuan memiliki efek signifikan $(P<0,01)$ pada parameter yang diamati. Perlakuan dengan tingkat pemupukan sebanyak $15000 \mathrm{~kg}$ pupuk organik/ha/tahun memberikan hasil yang optimal untuk semua parameter yang diukur.
\end{abstract}

Kata kunci: lahan kering, pupuk organik, rumput gajah mini

\begin{abstract}
Manure application is beneficial to crop growth. In Indonesia, use of dwarflate napier grass can be an effective strategy to enhance its utilization as the feed resources suitable for ruminant livestock. The objective of this study was to determine of the influence of organic fertilizer on the growth of dwarflate napier grass on marginal land at the second year after establishment. This research was carried out in Galung Village, Barru Subdistrict, Barru Regency on January until August 2019. Research design was Completely Randomized Design (CRD) with 4 treatments and 3 replications consisting of control: $0 \mathrm{~kg}$, low: $5000 \mathrm{~kg}$, medium: $10000 \mathrm{~kg}$ and high: $15000 \mathrm{~kg}$ of organic fertilizer/ha/year, respectively. The variables observed included plant height, plant length, number of tillers, leaf surface area, weights of leave blade (LB), stem with leave sheath (ST), dry (D) and total dry matter (TDM). The data collection was carried out at the age of 2 months every cuttings time for the first, second, third, and fourth, respectively. Statistical analysis was made by SPSS. The results of the diversity analysis showed that the treatments had significant effect $(P<0.01)$ on the observed parameters. The treatment with a level of fertilizer as much as $15000 \mathrm{~kg}$ of organic fertilizer/ha/year gives optimal results for all parameters measured.
\end{abstract}

Keywords: dwarflate napier grass, manure, marginal land

\section{PENDAHULUAN}

Alih fungsi padang penggembalaan merupakan salah satu masalah yang kini dihadapi oleh sektor peternakan ruminansia. Padang penggembalaan yang fungsi utamanya adalah sebagai sumber hijauan pakan dan tempat ternak berinteraksi, harus tergerus 
dengan tuntutan kebutuhan masyarakat utamanya dalam sektor pembangunan fisik serta bentuk alih fungsi lainnya. Kondisi ini diperparah dengan kualitas lahan padangan yang saat ini ikut menurun karena para peternak pada umumnya tidak mengelola padang penggembalaan yang ada dengan baik. Hal tersebut dapat dilihat dari turunnya produksi hijauan pakan di padang penggembalaan yang hampir terjadi pada seluruh wilayah di Provinsi Sulawesi selatan.

Pemanfaatan lahan marginal merupakan salah satu langkah yang dapat diambil guna memenuhi kebutuhan pakan ternak. Lahan marginal secara prinsip dapat dioptimalkan penggunaannya apabila faktor pembatasnya dapat diselesaikan seperti ketersediaan air dan ketersediaan hara tanah dengan harapan rumput yang ditanam dapat tumbuh secara optimal sehingga menghasilkan produksi yang tinggi dan kualitas nutrisi yang baik.

Produksi rumput gajah mini sangat bervariasi dan dipengaruhi oleh berbagai faktor, antara lain agroklimat, jarak tanam dan manajemen budidaya. Tanpa membedakan musim di saat panen, di Malaysia produksi BK rumput gajah mini per panen bisa mencapai 8,7 ton/ha dengan kumulatif produksi BK sebesar 55,9 ton/ha/tahun pada jarak tanam $50 \times 100 \mathrm{~cm}$ (Halim et al., 2013). Rumput Gajah mini merupakan salah satu jenis pakan ternak yang berkualitas tinggi dan disukai ternak, dapat hidup dibeberapa tempat $(0-3000 \mathrm{dpl})$, tahan lindungan, respon terhadap pemupukan, serta dapat hidup dan bertumbuh pada tanah yang kurang subur (Wadi et al., 2007).

Penelitian tentang pemberian slurry (limbah biogas) pada rumput gajah mini pada dasarnya pernah dilakukan oleh Sunusi et al. (1998) dan Hasyim et al. (2004) pada lahan normal. Dari hasil penelitian tersebut dikemukakan bahwa kandungan nitrogen dari total bahan kering dan semua komponen tanaman rumput gajah mini dan kandungan nitrogen anorganik dalam tanah akan meningkat seiring dengan peningkatan dosis pupuk kandang berturut-turut dari 20 ton/ha, 40 ton/ha dan 60 ton/ha. pemberian pupuk organik cair kompos (slurry or digested effluent of manure) sebagai pupuk dasar berpengaruh nyata terhadap pertumbuhan hijauan, produksi, jumlah anakan dan kandungan protein serta In
Vitro dry matter digestibilyty (IVDMD) rumput gajah mini lambat berbunga (Wadi et al., 2007). Dari data penelitian tersebut, kesimpulan awal yang dapat diambil adalah rumput gajah mini (Dwarf late napiergrass) pada prinsipnya dapat dilakukan pada lahan kurang subur dengan manajemen pemeliharaan yang baik.

Penelitian ini bertujuan untuk mengetahui pengaruh pupuk organik terhadap pertumbuhan rumput gajah mini di lahan marginal pada tahun kedua setelah penanaman. Hasil penelitian diharapkan dapat menjadi rujukan peternak atau kalangan intelektual peternakan dalam memanfaatkan lahan marginal sebagai media tumbuh atau padang penggembalaan rumput gajah mini.

\section{BAHAN DAN METODE}

\section{Waktu dan Tempat Penelitian}

Penelitian ini dilakukan di Desa Galung, Kecamatan Barru, Kabupaten Barru Provinsi Sulawesi Selatan dari bulan Januari hingga Agustus 2019.

\section{Rancangan Penelitian}

Desain penelitian yang diterapkan adalah Rancangan Acak Lengkap (RAL) dengan 4 perlakuan dan 3 ulangan berurutan yang terdiri dari Kontrol : $0 \mathrm{~kg}$, rendah: $5000 \mathrm{~kg}$, sedang: $10000 \mathrm{~kg}$, dan tinggi: $15000 \mathrm{~kg}$ pupuk organik/ha/tahun (Gasperz, 1991). Variabel yang diamati meliputi tinggi tanaman, panjang tanaman, jumlah anakan, luas permukaan daun, berat daun, berat batang, berat kering dan berat keseluruhan tanaman. Pengumpulan data dilakukan pada setiap umur tanaman 2 bulan untuk pemotongan pertama, kedua, ketiga, dan keempat. Kegiatan ini diawali dengan melakukan observasi lahan guna menentukan titik tanam penelitian lalu dilanjutkan dengan pembajakan dan penggaruan lahan. Untuk penyediaan bibit rumput, diawali dengan melakukan pembibitan pada polybag yang kemudian dilanjutkan dengan transplanting pada lahan yang sudah siap pada tahun 2018. Analisis kadar air, $\mathrm{N}$ dan $P$ tanah dilakukan di Laboratorium Kimia Makanan Ternak Fakultas Peternakan Universitas Hasanuddin, Makassar. 


\section{Analisa Data}

Semua data hasil penelitian dianalisis secara statistik menggunakan software SPSS untuk mengetahui pengaruh perlakuan yang diterapkan terhadap variabel pertumbuhan rumput gajah mini.

\section{HASIL DAN PEMBAHASAN}

Tinggi tanaman merupakan salah satu bagian yang sangat penting dalam menghitung produksi rumput yang diukur dari titik tumbuh rumput (dasar) sampai dengan ujung daun yang tegak berdiri. Pada Gambar 1, tinggi tanaman maksimal terjadi pada bulan Februari atau pengukuran/pemanenan rumput pertama kemudian diikuti dengan April, Juni dan September. Dengan perlakuan yang sama terdapat perbedaan tinggi tanaman yang disebabkan karena curah hujan tertinggi pada bulan Februari. Selain itu tinggi tanaman tertinggi pada bulan Februari disebabkan karena pada bulan Februari adalah pemotongan pertama sehingga produksi maksimal pada bulan tersebut.

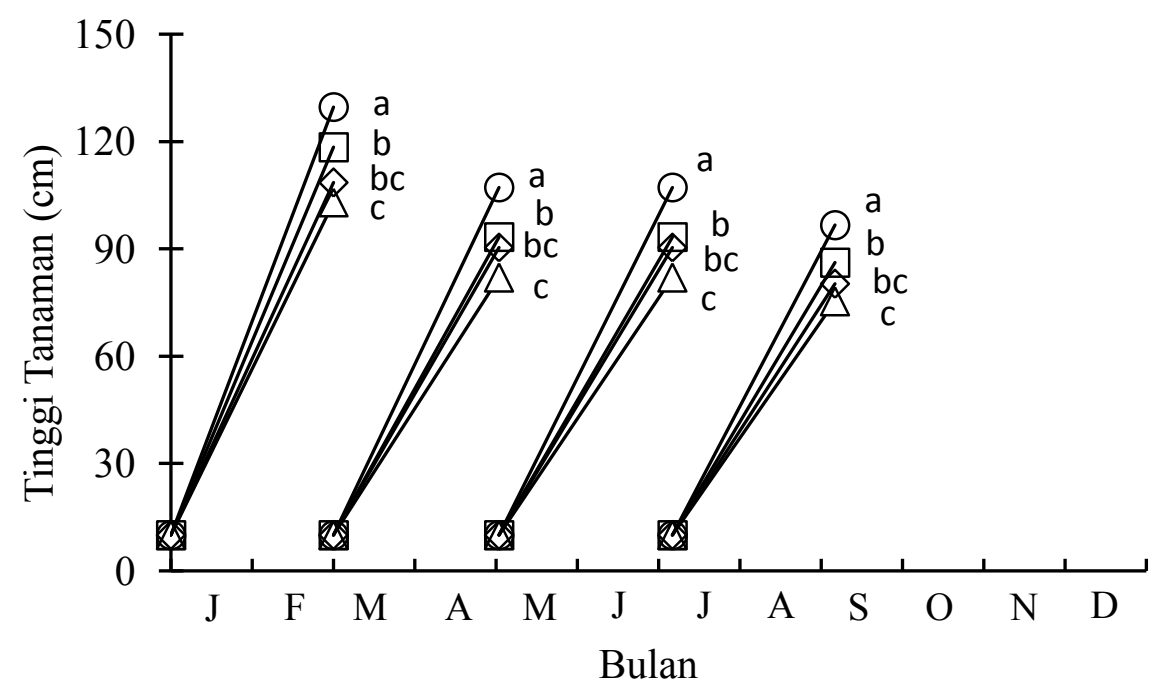

Perlakuan : kontrol $(\Delta)$, rendah $(\diamond)$, tengah $(\square)$ dan tinggi $(\circ)$ tingkat pupuk

Gambar 1. Grafik pertumbuhan tinggi tanaman rumput gajah mini.

Grafik pertumbuhan tinggi tanaman rumput gajah mini menunjukkan bahwa pada keempat masa pemanenan terlihat bahwa tanaman yang paling tinggi yaitu pada perlakuan tingkat pemupukan tinggi. Hal tersebut disebabkan karena kandungan pupuk kandang dapat memperbaiki pertumbuhan tanaman. Rivaie (2006) menyatakan bahwa pupuk kandang sapi mempunyai komposisi kandungan unsur hara yang lengkap, tetapi jumlah tiap jenis unsur hara tersebut rendah walaupun kandungan bahan organik di dalamnya sangatlah tinggi. Selanjutnya dikatakan bahwa pemberian pupuk organik cair kompos (slurry or digested effluent of manure) sebagai pupuk dasar berpengaruh nyata terhadap pertumbuhan hijauan, produksi, jumlah anakan dan kandungan protein serta kecernaan bahan kering secara in vitro (In Vitro dry matter digestibilyty/ IVDMD) rumput gajah mini lambat berbunga (Wadi et al., 2007). 


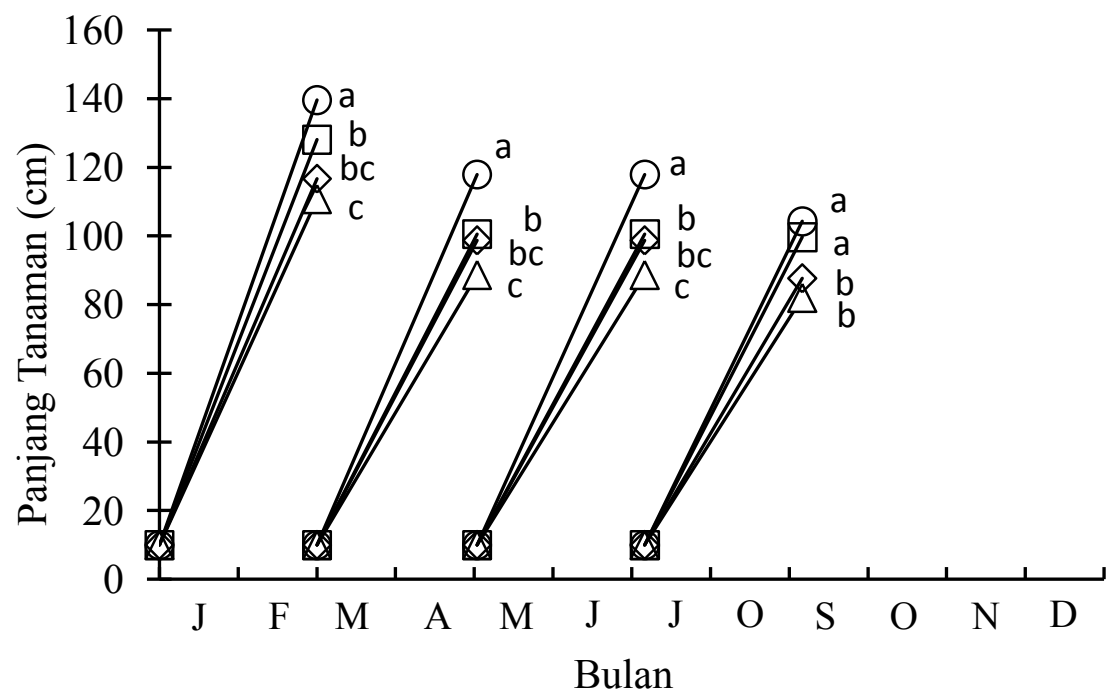

Perlakuan : kontrol $(\Delta)$, rendah $(\diamond)$, tengah $(\square)$ dan tinggi $(\circ)$ tingkat pupuk

Gambar 2. Grafik pertumbuhan panjang tanaman rumput gajah mini.

Gambar 2 diatas menunjukkan bahwa tanaman yang paling panjang yaitu pada perlakauan pemupukan menggunakan pupuk kandang dosis tinggi pada semua fase pemotongan, hal tersubut disebabkan karena menurut Patil (2010) bahwa pemberian pupuk organik dapat meningkatkan pertumbuhan tanaman, klorofil, karbohidrat dan protein dibandingkan dengan pupuk urea.

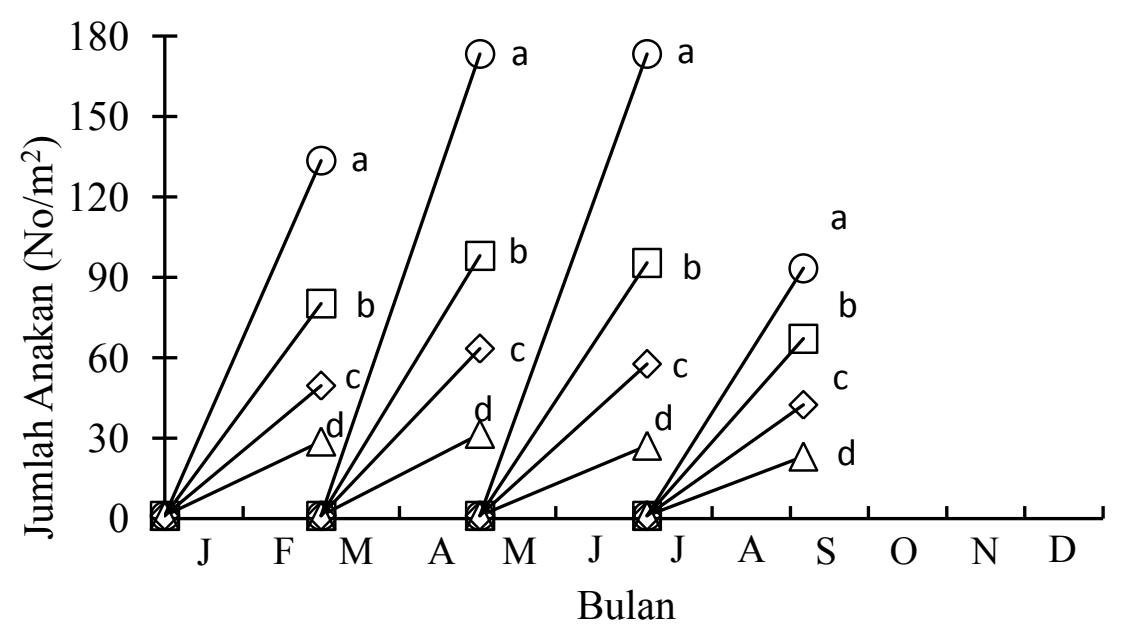

Perlakuan : kontrol $(\Delta)$, rendah $(\diamond)$, tengah $(\square)$ dan tinggi (०) tingkat pupuk

Gambar 3. Grafik jumlah anakan tanaman rumput gajah mini.

Pada Gambar 3 terlihat bahwa jumlah anakan tertinggi pada perlakuan pemupukan dosis tinggi, parameter jumlah anakan ini sejalan dengan parameter pertumbuhan lainnya. Santia 
et al. (2017) menyatakan bahwa jumlah tunas atau anakan merupakan indikator kemampuan hijauan pakan untuk bertumbuh kembali

sekaligus sebagai tanda potensi menghasilkan biomassaa yang tinggi.

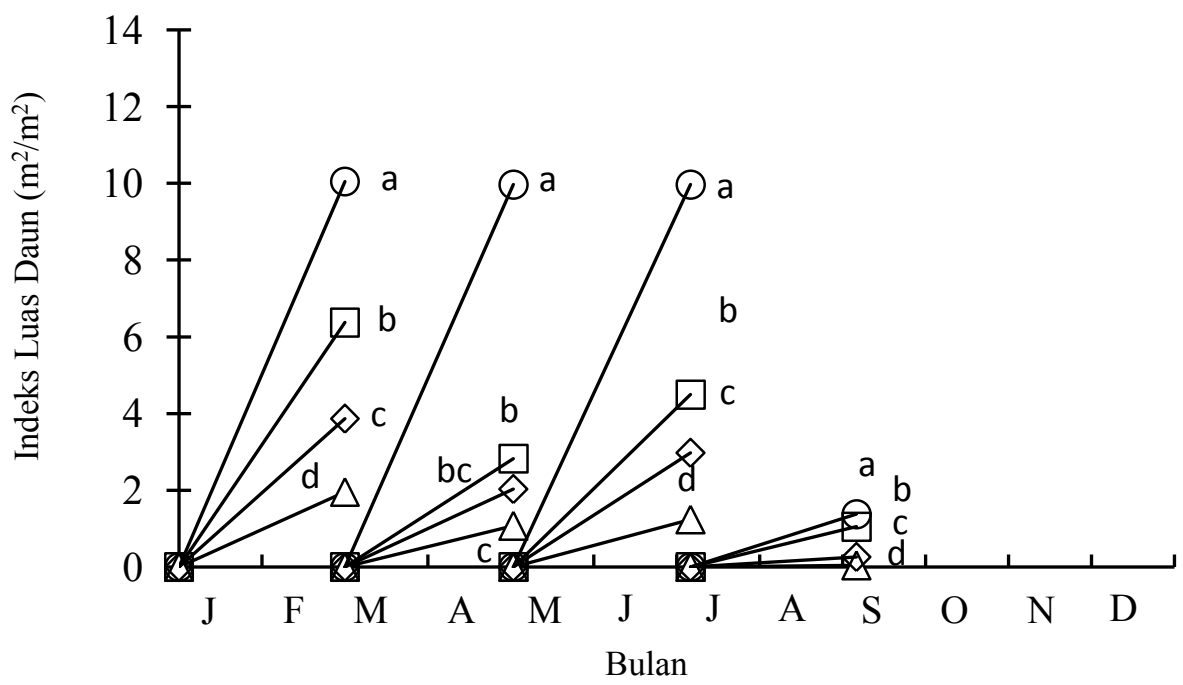

Perlakuan : kontrol $(\Delta)$, rendah $(\diamond)$, tengah $(\square)$ dan tinggi $(\circ)$ tingkat pupuk

Gambar 4. Grafik indeks luas dauntanaman rumput gajah mini

Pemupukan menggunakan pupuk kandang dengan dosis tinggi pada penelitian ini memberikan indeks luas daun tertinggi dibandingkan dengan perlakuan lainnya. Hal tersebut berlaku untuk semua fase pemotongan. Khrisnamorty (1981, dalam Sahari 2005) menyatakan bahwa luas daun erat kaitannya dengan kemampuan tumbuh untuk menghasilkan asimilat yang selanjutnya akan berpengaruh terhadap pertumbuhan tanaman. Hal ini dibuktikan dengan pertumbuhan tanaman dan luas indeks daun tertinggi pada perlakuan dengan dosis pemupukan tertinggi pula. Hal ini disebabkan karena luas daun akan berpengaruh pada penentuan jumlah energi matahari yang akan diserap oleh daun sehingga akan menentukan jumlah fotositat yang diserap (Salisbury dan Ros, 1992; Maya Dewi, 2007).

\section{KESIMPULAN}

Tinggi tanaman, panjang tanaman, jumlah anakan dan indeks luas daun bertambah meningkat seiring bertambahnya tingkat pemupukan. Perlakuan dengan tingkat pemupukan sebanyak $15000 \mathrm{~kg}$ pupuk organik/ha/tahun memberikan hasil yang optimal untuk semua parameter yang diukur.

\section{DAFTAR PUSTAKA}

Gasperz, V. 1991. Metode Rancangan Percobaan. CV. Armico, Bandung.

Halim M.R.A, Samsuri S, dan Bakar I.A. 2013. Yield and nutritive quality of nine napier grass varieties in Malaysia. Malaysian Journal of Animal Science Vol. 16(2): 3744.

Hasyim, H. 2004. Effect of the Level of Manure Application on the Growth, Plant and Soil Mineral Properties in napiergrass (Pennisetum purpureum Schumach). Master Thesis, Miyazaki University. Japan

Krishnamoorthy, H.N. 1981. Plant Growth Substances Including Applications in Agriculture. Tata Mc. Graw Hill, Publishing Co. Ltd., New York. 50 p. 
Mayadewi, N.N.A. 2007. Pengaruh jenis pupuk kandang dan jarak tanam terhadap pertumbuhan gulma dan hasil jagung manis. Agritrop Vol. 26(4) : 153-159.

Patil, N.M. 2010. Biofertilizer effect on growth, protein and carbohydrate content in Stevia rebaudiana Var Bertoni. Recent Research in Science and Technology Vol. 2(10): 4244.

Rivaie, A. 2006. Pupuk Kandang Sapi. PT. Kreatif Energi Indonesia. http://www.indobiofuel.com/menu\%20artike I\%20jarak\%209. Online. Diakses pada 17 Juni 2019.

Sahari, P. 2005. Pengaruh jenis dan dosis pupuk kandang terhadap pertumbuhan dan hasil tanaman Krokot Landa (Talinum triangulare Willd). Jurnal IImiah Agrineca 7(1): 36-42.

Salisbury, F.B. dan Ross, C.W. 1992. Plant Physiology. 4th Ed. Wadsworth Publishing Company Bellmount, California. 681 hal.
Santia, Anis, S.D. dan Kaunang, C.L. 2017. Pengaruh tinggi dan jarak waktu pemotongan rumput gajah Dwarf (Pennicettum purpureum CV. Mott) terhadap pertumbuhan vegetatif dan produksi bahan kering. Jurnal Zootek Vol. 37(1): 116-122.

Sunusi, A.K., Ito, K., Tanaka, S., Ishii, Y., Ueno, M. dan Miyagi, E. 1998. Yield and digestibility of napier grass (Pennisetum purpureum Schumach) as affected by the level of manure input and the cutting interval. Japanese Journal of Grassland Science Vol. 43: 209-219.

Wadi, A., Ishii, Y., Hasyim, H. dan Idota, S. 2007. Rotational grazing effects on dwarf napier grass at a paddock scale by dairy cows in Miyazaki. Japanese Journal of Grassland Science Vol. 53 (Ext): 46-47. 